\title{
The translation of Hebrew flora and fauna terminology in North Sámi and West Greenlandic fin-de-siècle Bibles ${ }^{1}$
}

\begin{abstract}
This study is a comparative analysis of the strategies employed in the translation of geographically specific flora and fauna terminology in the first complete Hebrew Bible translations into North Sámi (1895) and West Greenlandic (1900). These two contemporaneous translations lend themselves to fruitful comparison because both North Sámi and Greenlandic are spoken in the Arctic by the indigenous communities which share a similar history of colonisation by Lutheran Scandinavians. Despite this common background, our study reveals a striking difference in translation methods: the North Sámi translation exhibits a systematic foreignising, formally equivalent approach using loan words from Scandinavian languages (e.g. šakkalak 'jackals' from Norwegian sjakaler, granatæbel 'pomegranate' from Norwegian granateple), whereas the Greenlandic translation typically creates descriptive neologisms (e.g. milakulâk 'the spotted one' for 'leopard') or utilises culturally specific domesticating, dynamically equivalent Arctic terms (e.g. kingmernarssuak 'big lingonberry' for 'pomegranate'). The paper assesses the reasons behind these different translatorial approaches.
\end{abstract}

Key words: translation, translation strategies, Sámi, Greenlandic, foreignising, domesticating, Arctic, Hebrew Bible, flora, fauna

\section{Introduction}

The purpose of this article is to investigate domestication and foreignisation of geographically specific Hebrew terminology for ancient Near Eastern flora and fauna in two contemporaneous Arctic Bible translations, one North Sámi and one West Greenlandic. North Sámi is a FinnoUgric language spoken in northern Norway, Sweden, and Finland by around 25,000 people. West Greenlandic (also known as Kalaallisut or Greenlandic) is an Eskimo-Aleut language and the sole national language of Greenland. It is spoken by around 55,000 people. Both languages are spoken by indigenous Arctic peoples that have been under Scandinavian rule for several hundred years (Danish and to a lesser extent Norwegian in the case of Greenlandic, and Danish/Norwegian, Swedish, and Finnish in the case of Sámi), and as such have been heavily influenced by these dominant cultures and languages.

As a consequence of Scandinavian colonisation, both the Sámi and Greenlandic peoples have been Lutheran for the past several centuries. The first North Sámi translation of the New Testament was produced by the Norwegian missionary Nils Stockfleth and published in 1840. The entire Bible appeared in 1895, translated by a committee of the Norsk Finnemisjon (now

\footnotetext{
${ }^{1}$ The authors would like to express their deepest gratitude to Naja Motzfeldt for her numerous insightful and helpful comments on the Greenlandic portions of this article.
} 
known as the Norwegian Sámi Mission), and published in Oslo. This translation has remained the only North Sámi Bible version until very recently when the entire Bible in a modern rendition was published online by the Norwegian Bible Society. Partial Bible translations into Greenlandic were undertaken over the course of the eighteenth century, with the first complete New Testament published in 1766. Various portions of the Old Testament were translated during the nineteenth century, but the first complete Bible in Greenlandic did not appear until 1900. This translation was produced by Samuel Kleinschmidt (1814-1886), the son of a Moravian missionary father and a Danish mother who was born in Greenland and spoke Greenlandic as a native language. He passed away before his translation was finished and it was published posthumously. See Kleivan $(1979,176)$ and Nielsen (2012) for the early history of Bible translations into Greenlandic. Kleinschmidt's work remained the only Greenlandic Bible version until 2000, when a new translation was published by the Danish Bible Society. In the case of both the North Sámi and the Greenlandic translations, the translators are likely to have used a wide range of source materials and tools, including the original Hebrew, and also Scandinavian, German, Greek, and Latin versions, as well as previously translated North Sámi and Greenlandic extracts. A more detailed analysis of the translators' methods is beyond the scope of this study.

A particular challenge relating to the examination of the translation of fauna and flora in the Hebrew Bible is the uncertainty regarding the meaning of many of the original Hebrew terms (see Naudé and Miller-Naudé 2018 for analysis of the problems relating to the translation of biblical fauna and flora terminology owing to these uncertainties; see e.g. Hope 2005; Koops and Slager 2012; Musselman 2012; United Bible Societies 1980; Zohary 1962, 1973, 1982) for discussion of the meanings of the original Hebrew terms based on historical, archaeological, and scientific evidence). Because much of this present-day knowledge was not available to the North Sámi translators or to Kleinschmidt and because their work was at least partially conducted indirectly via Scandinavian Bible translations, it is difficult to ascertain how familiar they would have been about the original reference of these terms in their ancient Near Eastern context. As such, our examination focuses on the translation strategies which they used rather than on the relationship between their target texts and the precise meanings of the original Hebrew terms as they are understood according to current scholarship.

We have selected the fin-de-siècle translations as the basis of this investigation because they are the first complete Bible versions to appear in North Sámi and Greenlandic respectively, and were produced at roughly the same time, and both reflect very similar cultural, historical, and religious (Arctic, Nordic, and Lutheran) circumstances. As such, these early translations 
offer a fruitful corpus for the study of translation strategies regarding culturally and geographically specific Hebrew terminology, namely Near Eastern flora and fauna, which lacked autochthonous equivalents in the North Sámi- and Greenlandic-speaking environments. These semantic fields are extremely instructive areas to examine from a translation studies perspective because the Arctic environment of North Sámi and Greenlandic speakers is strikingly different from the Near Eastern setting of the Hebrew Bible that translators would not have had readily available native equivalents at their disposal at the end of the nineteenth century, and would thus have been forced to make conceptual decisions about how to render such terms into the target language.

We examine the chosen lexical items from the perspective of Eugene Nida's (1964, 1969) and Nida and Taber's (1969) framework of formal vs dynamic equivalence, i.e. the practice of literally translating culturally specific concepts (perhaps by using a word borrowed from the source language rather than paraphrasing or replacing it) vs the mechanism by which translators may alter content that would be difficult for the target audience to understand if translated literally. Of similar relevance to this study is the contrast between foreignising and domesticating translation strategies, with the former utilising terms from the source language while the latter employs target language equivalents (see Venuti 2008). We also acknowledge the complexity theory approach (Marais 2014, 2019), which recognises that translation choices are not a simple dichotomy (e.g. between domesticating and foreignising) but rather the result of numerous complex underlying economic, political, societal, and theological, translation factors. Due to space constraints we cannot analyse all of these factors in detail; our focus is limited to the cultural and environmental factors underlying the translators' decisions.

This article will examine the North Sámi and Greenlandic translations with a view to ascertaining whether the shared cultural, historical, and religious background that produced them resulted in similar or different strategies for introducing foreign concepts relating to flora and fauna to the Arctic target audience. To this end we will show relevant extracts from the two Bible versions accompanied by English back translations, analyse the etymologies, morphologies, meanings and cultural associations of the words, and evaluate the motivations behind the translatorial approaches encountered. As this article constitutes the first comparative analysis of fauna and flora terminology in Arctic Bible translations, we have chosen to place our focus on the examination of the linguistic data in order firmly to establish the overarching translational trends in the two versions.

The article fits into the broader study of techniques for dealing with geographically specific biblical terminology, particularly flora and fauna, in translation (see e.g. Koops 1995, 
1998; Du Toit and Naudé 2005; Miller-Naudé and Naudé 2018; Naudé and Miller-Naudé 2018). More specifically in the Arctic context similar challenges have been noted in the translation of words for biblical flora and fauna such as 'camel', 'sheep', etc. into twenty-firstcentury Inuktitut from Arctic Canada (Posner 2012) and in the early translation of biblical fauna into Cree (Careless 2001).

\section{$2 \quad$ Fauna}

The North Sámi and Greenlandic translators typically take very different approaches to the translation of the geographically specific terms for animals appearing in the Hebrew Bible. The North Sámi translators systematically opt for a foreignising approach involving borrowings from Norwegian, which correspond closely in meaning to the zoological reference of the original Hebrew but might not be immediately familiar to the target audience; by contrast, Samuel Kleinschmidt, the translator of the Greenlandic Bible, typically chooses a more domesticating solution involving a dynamic equivalent composed of descriptive terms which would be more easily visualised by the Greenlandic readership. A clear example of these trends can be seen in the case of the words תנים 'ostriches' appearing in the following verse:

The wild animals will honor me,

the jackals and the ostriches (Isa 43.20 NRSV)

The North Sámi version shown below employs a foreignising solution to denote these two animals, which were unknown in northern Scandinavia:

mæccespirik, šakkalak ja struzza-loddek, galggek gudnijattet muo 'wild beasts, jackals and ostrich-birds, will honour me'

The term šakkalak 'jackals' (šakalat in the modern North Sámi orthography) is a borrowing from Scandinavian languages (cf. Norwegian sjakal), as is struzza (modern struhcca) 'ostrich' (cf. Norwegian struts). Interestingly, the translators have added the explanatory word loddek (modern lottit) 'birds', to help orientate readers who might be unfamiliar with this borrowed term for a bird that does not inhabit the Scandinavian Arctic region.

The Greenlandic version differs markedly from the North Sámi one; instead of employing Danish borrowings it opts for two descriptive terms: 
narssap, nerssutaisa nâlangnartísavānga, Kingmit nujuartat Katigagtûssatdlo 'the wilderness' beasts will praise me, wild dogs and back-like ones'

The Greenlandic term Kingmit nujuartat 'wild dogs' (qimmit nujuartat in the modern Greenlandic orthography) is a dynamic equivalent to 'jackals' that would make the sense immediately accessible to the target audience, while rendering the verse more distant in literal reference from the Hebrew original, which is rooted in a geographic context unfamiliar to the Greenlandic readership. The Greenlandic translation of the term for 'ostriches' is again a descriptive term based on the noun Katigak (modern qatigak) 'back', followed by the participial suffix -toK (modern -toq), and then the suffix -usaK (modern -usaq) 'something resembling', the entire word meaning 'something resembling something which has a back'.

The same tendency can be seen in the following verse, which contains a number of references to camels and donkeys, two types of animals that are native to the ancient Near East but not to the Arctic:

thirty milch camels and their colts, forty cows and ten bulls, twenty female donkeys and ten male donkeys (Gen 32.15 NRSV)

The North Sámi translation employs a typically foreignising approach, using the Scandinavian loanwords kamela 'camel' and asen (modern ásen) 'donkey' (cf. Norwegian kamel 'camel'; Swedish åsna 'donkey'):

golbma loge njamatægje kamela oktan dai čivgaiguim, njælje loge gusa ja loge vuovsa, guokte loge njingelas asena login čivgain 'thirty nursing camels together with their young, forty cows and ten bulls, twenty female donkeys with ten young'

By contrast, the Greenlandic translation opts for a characteristically descriptive approach:

Katigagtût milugtugdlit pingasunik Kuligdlit piaraitdlo, ugsigit arnavíssat sisamanik Kuligdlit ugsigitdlo angutivíssat Kulit, siutitût Kimugtigingnerit mardlungnik Kuligdlit, siutitûdlo Kimugtugssarigsut Kulit. 
'thirty sucking big-backed ones and their young, forty cows and ten bulls, twenty draft donkeys and ten future draft (= young) big-eared ones'

Kleinschmidt's term for 'camel' is Katigagtôk (modern qatigattooq), which has the literal meaning of 'something with a big back'. It is comprised of the noun Katigak (modern qatigak) 'back' combined with the suffix -tôK (modern -tooq) 'something possessing a big X'. Similarly, the word for 'donkey', siutitôk (modern siutitooq), meaning 'something with big ears', is based on the word siut 'ear' combined with the same suffix -tôK (modern +tooq).

The following verse from Isaiah further illustrates the difference in translatorial approach between the North Sámi and Greenlandic versions. This verse contains references to the animals זמר 'wolf' and 'leopard':

The wolf shall live with the lamb, the leopard shall lie down with the kid (Isa 11.6 NRSV)

The North Sámi translation is shown below.

Ja gumppe galgga orrot labba lutte, ja pardar vællat gice balddast 'and the wolf will live with the lamb, and the leopard will lie next to the kid'

This translation illustrates two points about the North Sámi translatorial approach. First, the term pardar 'leopard' illustrates the same foreignising tendencies discussed above: the word, referring to an animal unknown in the Scandinavian Arctic, is a borrowing ultimately deriving from the second component of the Latin name Panthera pardus (cf. also the term $\pi \alpha \alpha^{\rho} \delta \alpha \lambda 1 \varsigma$ appearing in the Greek version of this verse, which the North Sámi translators are likely to have consulted in addition to the Hebrew). Second, the term gumppe (modern gumpe) 'wolf' illustrates a case of an animal which, in contrast to the examples discussed previously, does exist in the North Sámi-speaking environment; as such, the standard North Sámi term, which would have been instantly familiar to the target audience for whom wolves are a common fixture of the local environment, has been selected. Likewise, goats are a longstanding feature of the Sámi landscape, and as such there is an established North Sámi word for them, gicce (modern gihcci).

The Greenlandic version of this verse, shown below, illustrates Kleinschmidt's very different approach: 
amarkup najúsavâ savârak, milakulâvdlo savaurssârak акuрекаtigísavâ 'the (Arctic) wolf will live with the lamb, and the one with small spots will lie with the little one that resembles a lamb'

In contrast to northern Scandinavia, wolves are not commonly found in Greenland; while there is an Arctic wolf, it is rare in Greenland, being much more typically associated with the Canadian Arctic. The Greenlandic word amarok (modern amaroq) '(Arctic) wolf' thus traditionally refers specifically to this Canadian wolf (Kleivan 1979, 184) and as such has particular cultural and geographic connotations that change the sense of the line. In this case the translation strategy is domesticating.

The Greenlandic translation for 'leopard' reflects a descriptive approach similar to that discussed in previous examples. Kleinschmidt's Greenlandic word, milakulâk (modern milakulaaq), is derived from the base milak 'spot, freckle' followed by a nominalising suffix with a diminutive sense. This choice provides readers with a vivid description of the animal in question, which would allow them to visualise its appearance even though it is not a feature of the local environment. Similarly, the word for kid, savaurssârak (modern savaasaaraq), is a compound made up of the word sava 'sheep' followed by the suffix -asak (modern -asaq) 'something that resembles', followed by the diminutive suffix -arak (modern -araq), giving the literal meaning of 'a small thing resembling a sheep'. This reference to 'sheep' is based on the fact that sheep were brought Greenland much earlier than goats (see below for a discussion of the Greenlandic word sava 'sheep'), and when goats first arrived in the country the word describing them was formed on analogy with the pre-existing word for 'sheep'.

Another example of the difference between the North Sámi and Greenlandic translators' approaches to the rendition of animal terms can be seen in the case of נחש 'serpent' appearing in Gen 3.1:

Now the serpent was more crafty than any other wild animal that the LORD God had made (Gen 3.1 NRSV)

The North Sámi translation is as follows:

Ja gærmaš læi gavvelæbbo go buok mæce spirik, maid Ibmel Hærra læi dakkam 'and the snake was more cunning than all the beasts of the wilderness that the LORD God had made’ 
Like wolves, snakes are a feature of the northern Scandinavian environment and there is an established North Sámi term for them. As such, the use of this term in the North Sámi translation is unsurprising and there is no need for either a foreignising or domesticating solution.

Again, the Greenlandic translation offers a different perspective:

Pulateriârssugdle perkusersûneruvoK narssap nerssutainit tamanit Gûtip Nâlagkap piliarissainit

'and the bad earthworm was more clever than all the beasts of the field which God the LORD had made'

In contrast to northern Scandinavia, Greenland does not have snakes or other serpents. Instead of using a Danish borrowing to refer to this non-native reptile, Kleinschmidt's translation employs a descriptive Greenlandic word, pulateriârssuk (modern pulateriaarsuk) 'snake', which is based on the noun pulateriak (modern pulateriaq) 'earthworm' (itself derived from the verb pulavoK [modern pulavoq] 'creep, crawl') combined with the suffix -arssuk (modern -arsuk), meaning 'bad', i.e. 'bad earthworm'. This term would have easily created a frame of reference for the target audience irrespective of whether they were familiar with snakes.

The following extract from 2 Chronicles contains a reference to שנהבים 'ivory', which represents a similar challenge to the Greenlandic and North Sámi translators as elephants are unknown in the Arctic environment:

gold, silver, ivory, apes, and baboons (2 Chr 9.21 NRSV)

The North Sámi version employs a loanword in its translation of 'ivory', as shown below:

golle ja silba, elefanta-banid ja abegatoid ja po-loddid 'gold and silver, elephant teeth and apes and peacocks'

The phrase elefanta-banid (modern elefántabániid) 'elephant's teeth' for 'ivory' appears to be an instance of phono-semantic matching from Scandinavian languages: the word for 'ivory' in Norwegian is elfenbein, both of which literally mean 'elephant's bone'. The Norwegian 
word for 'bone', bein, sounds similar to the North Sámi word banid (modern bániid), meaning 'teeth' (which is also close in meaning to 'bone'). The word for elephant, elefanta (modern elefánta), is a direct loanword from Scandinavian languages (cf. Norwegian elefant).

As in the cases discussed above, Kleinschmidt's version offers a different solution:

kûltimik sîlvimigdlo tûgânigdlo âpakânigdlo pâvûnigdlo

with gold and silver and (narwhal) tusks and apes and baboons

This verse constitutes a striking case of domestication. The word tûgâk (modern tuugaaq) 'tusk' does not refer specifically to the tusk of an elephant; rather, it is most closely associated with the noun tûgâlik (modern tuugaalik) 'narwhal', which literally means 'tusked one'. The narwhal (Monodon monoceros) is a medium-sized whale with a single long tusk that is native to the Arctic region, including Greenland. The use of the word tûgâK (modern tuugaaq) as an equivalent of 'ivory' has the unmistakeable effect of situating the Greenlandic version in an Arctic context, which is all the more remarkable given that the surrounding vocabulary items are loanwords describing materials and animals from distant cultures (to be discussed below).

There are only rare exceptions to the Greenlandic strategy of employing descriptive terms to translate names of unfamiliar fauna appearing in the Hebrew Bible. One such case is the translation of the word for כבשים 'sheep', which appears in the following verse from Deuteronomy:

These are the animals you may eat: the ox, the sheep, the goat (Deut 14.4 NRSV)

The North Sámi translation is shown below:

Dak læk dak njæljejuolgag spirik, maid di oažžobetet borrat: Vuoksa, savcca ja gaicca 'these are the four-legged beasts, which you are allowed to eat: the ox, the sheep and the goat'

In this translation 'sheep' is rendered with the North Sámi word savcca (modern sávza), an old Scandinavian borrowing (cf. Old Norse sauðr, modern Norwegian sau). Sheep are a familiar animal in the North Sámi landscape, within the framework of a long tradition of sheep farming in Norway (Austrheim et al. 2008, 56-57). 
In contrast to the other Greenlandic terms discussed above, the Greenlandic translation of this term mirrors its North Sámi counterpart in that it likewise exhibits an old Scandinavian borrowing:

Máko tássa nerssutit nerisínaussase: ugsik, sava, savaussaK 'these are the land animals which you may eat: the ox, the sheep, the goat'

The Greenlandic word sava 'sheep', like the North Sámi savcca/sávza, is derived from the Old Norse sauðr. While sheep are not indigenous to Greenland, they have a long history in the country, featuring prominently in the agricultural system of the Norse settlement in southern Greenland between 985 and the mid-1400s (Austrheim et al. 2008, 44). As such, although technically a borrowed concept, the sheep was a well-known animal in the Greenlandic consciousness and language, and therefore the translation of this term did not require a descriptive term such as those found in the translation of fauna lacking such familiarity.

Another such case is the verse from 2 Chronicles discussed above, which in addition to its mention of 'ivory' refers to קופים ותוכיים. These two Biblical Hebrew terms have somewhat תוכיים has been interpreted variously as 'apes' or 'monkeys', while has been interpreted variously as 'parrots', 'peacocks', or 'baboons'. These varying interpretations of the terms are reflected in different translations of the Bible into diverse languages, including the Scandinavian, North Sámi, and Greenlandic ones. The North Sámi translation renders the two terms as 'monkeys and peacocks', while the Greenlandic one opts for 'apes and baboons'.

gold, silver, ivory, apes, and baboons (2 Chr 9.21 NRSV)

The North Sámi version translates 'apes' and 'peacocks' as follows:

golle ja silba, elefanta-banid ja abegatoid ja po-loddid 'gold and silver, elephant teeth and monkeys and peacocks'

These two terms are, as typical in such cases, borrowed from Scandinavian languages: abegatoid (modern ábegáhtuid) 'monkeys' is derived from the Norwegian apekatt, while poloddid (modern polottiid) 'peacock' is a blended calque based on the Norwegian påfugl 'peacock', which is a compound comprised of på (cognate with 'pea-' in English 'peacock') 
and fugl 'bird'. The first element of the North Sámi calque is a borrowing of the Norwegian på, while the second element is the North Sámi word for 'bird'.

In contrast to most other cases of unfamiliar fauna, here Kleinschmidt's translation contains two loanwords:

kûltimik sîlvimigdlo tûgânigdlo âpakânigdlo pâvûnigdlo

'with gold and silver and tusks and apes and baboons'

This choice is unexpected as it contrasts with Kleinschmidt's usual strategy of descriptive or domesticating solutions. In contrast to the example of sava 'sheep' discussed above, apes and baboons have never featured as part of the Greenlandic landscape. In this case, it is possible that Kleinschmidt chose not to provide a descriptive translation of these two terms because, in contrast to the other animals discussed above, 'apes' and 'baboons' closely resemble humans, and giving a description of 'human-like animals' is likely to have conflicted with his religious orientation. Rather than presenting readers with the notion of animals resembling humans, he instead opted to translate the two terms with a possibly unfamiliar loanword.

\section{Flora}

The Hebrew Bible contains numerous references to flowers and other plants native to the Near East (pomegranate, acacia, date palm, etc.). Most of these flora are foreign to the Arctic environment of the North Sámi- and Greenlandic-speaking regions. As in the cases of fauna discussed above, the North Sámi and Greenlandic translations have different ways of dealing with the translation of these regionally specific terms, with the North Sámi translation exhibiting a strong tendency towards foreignising solutions while the Greenlandic one usually opts for descriptive or domesticating terms.

These trends can be seen in the following example from Song of Songs, which contains the word רמון 'pomegranate':

Your cheeks are like halves of a pomegranate behind your veil (Song 6.7 NRSV)

The term for 'pomegranate' is translated as follows in the North Sámi version:

Nuftgo granatæbel-bitta læ du gæđaš du bæitaline duokken

'like pomegranate-piece is your temple behind your veil' 
The North Sámi term granatæbel (modern granahtaehpel) 'pomegranate' is a borrowing from Scandinavian languages (cf. Norwegian granateple).

By contrast, Kleinschmidt's translation includes a domesticating and descriptive term for the fruit rather than a loanword:

ulússavit kingmernarssûp agfai ássigait kīnavit sâguata tunuane 'your cheeks, your face behind the veil resemble half of a big lingonberry'

The Greenlandic word kingmernarssûp (modern kimmernarsuup; the absolutive/genitive form of the noun kingmernarssuaK [modern kimmernarsuaq]) derives from kingmernak (modern kimmernaq) 'lingonberry' (Vaccinium vitis-idaea). The lingonberry is the fruit of a shrub from the heath family which is native to the boreal forest and tundra in the Arctic regions of North America, Europe, and Siberia, including western and southern Greenland. The term for 'lingonberry' has been modified with the suffix -ssuaK (modern -suaq 'big'), resulting in a descriptive term meaning 'big lingonberry'. (Modern Greenlandic uses the Danish loanword granatæble.)

The contrast between the North Sámi and Greenlandic approach to the translation of words referring to non-native flora is also evident in Num 11.5, which contains a number of references to the edible plants that the Israelites recalled eating in Egypt. The first part of the verse, shown below, mentions two vegetables which are not a feature of the Arctic environment, קשטאים קשים 'cucumbers' andons':

We remember the fish we used to eat in Egypt for nothing, the cucumbers, the melons (Num 11.5 NRSV)

The North Sámi translation of this part of the verse reads as follows:

Mi muittep daid gulid, maid mi boraimek Egyptenest nuvta, njalgga šaddoid ja melonaid 'We remember that fish that we ate in Egypt for free, sweet plants and melons'

This translation exhibits a number of features which echo the foreignising choices discussed elsewhere in this article, namely the use of melonaid 'melons', a direct borrowing of the Scandinavian terms. However, it also deviates from the standard pattern of foreignising by its 
use of the descriptive term njalgga šaddoid (modern njálgga šattuid) 'sweet plants', instead of 'cucumbers'. This is a rare example of a descriptive translation strategy more closely resembling Kleinschmidt's preferred approach. It is unclear why in this case the translators opted for a descriptive solution rather than employing a loanword based on the Norwegian agurk (cf. modern North Sámi gurká). The phrase may be inspired by a similar term appearing in one of the source texts that the translators used.

Kleinschmidt's Greenlandic translation reads as follows:

aulisagkat erKaitdlârâvut Egivtinime nerissartagkavut akeKángitsut naussorssuitdlo putdlagaussat neKaussartôrssuitdlo

'we remember the fish in Egypt that we ate for free, and the big plants, the big swelling ones with a lot of meat'

This verse contains a number of noteworthy descriptive terms for edible plants which are not native to Greenland. First, the word for 'cucumbers', naussorssuit (modern naasorsuit), the plural of naussorssuak (modern naasorsuaq) is based on the root naussoK (modern naasoq), meaning 'something that grows', with a suffix -ssuak (modern -suaq 'big', meaning 'big plant'. The term for 'melons', putdlagaussat neKaussartôrssuit (modern pullagassat neqassartoorsuit) is based on the root putdlâ- (modern pullaa-), meaning 'swell' with the future suffix -ssaK (modern -ssaq) followed by neKe (modern neqi) 'meat, food' with the future suffix -ssaK (modern -ssaq), the suffix -tôK (modern -tooq), 'very', and the suffix ssuaK (modern -suaq) 'big' with the entire phrase literally meaning something like 'something big with a lot of meat that will swell up in the future'. (Modern Greenlandic uses the Danish loanword meloni).

A similar treatment can be seen in the translation of Job 40.21 (Job 40.16 in some Bible versions), which contains a reference to צאלים, a plural form referring to a plant whose precise meaning is unclear but may denote either a type of acacia or lotus (Even-Shoshan 2003, 5: 1563); the latter translation is reflected in the NRSV version shown below:

Under the lotus plants it lies, in the covert of the reeds and in the marsh (Job 40.21 NRSV)

In either case, the plant is one which is not found in the Arctic and therefore a choice must be made by translators deciding how to render it into North Sámi and Greenlandic. The North Sámi translation is typically foreignising, choosing the word 'lotus', which comes from 
Scandinavian languages. This follows the precedent of the Norwegian translation, which likewise translates צאלים as 'lotus'.

Lotusmiestagi vuolde dat vuoinad hoši ja suojo suoje vuoje.

'Under the lotus bush it rests, under the cover of the reeds and swamp'

Kleinschmidt, by contrast, finds a typically descriptive solution for this term:

orpît alángivfigdlit atāne patdlungassarpoK ivigssuarnut marugdlungmutdlo issertordlune. 'it lies on its stomach under the shadow-giving trees, in secret in the reeds and mud' 3

Kleinschmidt's choice, orpît alángivfigdlit (modern orpiit alanngiffillit), has the literal meaning of 'shadow-giving trees'. This translation is relatively far removed from the meaning of 'lotus', which Kleinschmidt might have perceived as challenging to describe. Likewise, it does not clearly evoke the 'acacia', another possible interpretation of the word, but may more closely resemble it since it is a tree that could cast shade. (The Hebrew term צאלים is also phonologically similar to the Hebrew word צל 'shade, shadow', which may have prompted Kleinschmidt's translation.)

The translation of the Hebrew word ג, which is typically understood to mean "coriander seeds', as in the following NRSV version, is another case in point.

The house of Israel called it manna; it was like coriander seed (Exod 16.31 NRSV)

The North Sámi translation, shown below, exhibits a typically foreignising solution:

Ja Israel viesso gočoi dam nama mannan; ja dat læi nuftgo koriander gilvvagak 'and the house of Israel called it by the name of manna; and it was like coriander seeds'

The translators have selected the word koriander 'coriander', a direct borrowing from Scandinavian languages. This is unsurprising given that coriander is not indigenous to the North Sámi-speaking regions of northern Scandinavia. The selection of this term, which would

\footnotetext{
${ }^{2}$ Note that this verse is Job 40.16 in the North Sámi version.

${ }^{3}$ Note that this verse is Job 40.16 in the Greenlandic version.
} 
not have been a feature of life in these areas in the late nineteenth and early twentieth centuries, would have been largely or totally unfamiliar to the target audience, and as such, the translation is a strongly foreignising one which makes no attempt to contextualise the term for readers (e.g. by the addition of a more general explanatory term such as 'plant' or 'herb'). This can be contrasted with their decision regarding the translation of 'ostrich' discussed in the previous section, where they added the contextualising term loddek (modern lottit) 'birds' to help clarify the unfamiliar term for the target audience.

Again, Kleinschmidt's translation takes a different approach:

Israîlíkutdlo tamáko taissarpait mánanik, tamákulo kuániarssuit nautsîagssartaisut íput 'and the Israelites called them manna, and they were angelica seeds'

Kleinschmidt has selected kuániarssuit (modern kuanniarsuit), a plural form based on the stem kuáneK (modern kuanneq), 'angelica' (Archangelica), an herb native to Greenland and other arctic and subarctic regions, which is used as a seasoning in food and as a kind of tea (see Gröntved 1954). The selection of this Greenlandic term clearly illustrates Kleinschmidt's strategy of systematically translating animal and plant names unfamiliar to Greenlandic readers either with highly descriptive neologisms that would be easily understood by readers, or dynamic equivalents from the target culture that would already have strong associations in the audience's mind from their own tradition.

As in the case of fauna discussed in the previous section, it is very rare for the Greenlandic translation to select a foreignising term to denote a plant unfamiliar to a fin-desiècle Greenlandic readership. An example of this unusual phenomenon is visible in the translation of Joel 1:12, which contains a list of a number of different geographically specific fruit trees and other plants, namely גפן 'vine', תאנה 'fig tree', רמון 'pomegranate tree', תמר 'palm tree', and תפוח 'apple tree':

The vine withers, the fig tree droops.

Pomegranate, palm, and apple-

all the trees of the field are dried up (Joel 1.12 NRSV)

In the North Sámi version, these plants, none of which is indigenous to the northern Scandinavia, have all been translated with loanwords from Scandinavian languages, as follows: 
Vidnemuorra læ goikkam, ja fikunmuorra læ astam; granatmuorra, maidai palbmemuorra ja æbelmuorra, buok ædnam muorak læk goikkam 'the wine-tree has dried up, and the fig-tree has withered; the pomegranate tree, also the palm tree and apple tree, all the earth's trees have dried up'

This Greenlandic verse exhibits a noteworthy deviation from the usual domesticating trend visible elsewhere in Kleinschmidt's translation:

vĩneKut ivsêrúpoK, figeKússuaK panernikûvok; kingmernarssuit palmitdlo paormatdlo neKaussaringnerit narssavdlo orpê tamarmik panerput

'the vine has no juice, the product of the big fig becomes dry; the pomegranate and the palm and the fruit, all the trees of the field are dry'

While some of these items (the words for 'pomegranate' and 'apple') have been translated by means of a domesticating or descriptive translation, a number of words in this passage, namely 'vine', 'fig', and 'palm', have been translated with Scandinavian borrowings, i.e. vĩneKut (modern viinnequt) 'vine', figeKússuak (modern figequssuaq) 'product of the big fig', and palmi 'palm'. The reason for this choice might be the fact that these three particular words were already most likely familiar to Greenlandic speakers at the time of Kleinschmidt's translation. Wine, and by extension grapevines, would have been known to Greenlanders as the drink already had an established presence in the country in the nineteenth century. Likewise, figs may have been familiar to Greenlanders as a dry foodstuff used on sea voyages. Similarly, palmi 'palm' would have been known to the target audience if only for its appearance in the compound palmit-sapaataat 'Palm Sunday', which had been a feature of Greenlandic life since the arrival of Christianity. Moreover, the words for 'grape' and 'fig' had been translated using Danish loanwords in earlier Greenlandic versions of the New Testament (Petterson 2012: 143).

\section{Conclusions}

This study has shown that despite the very similar cultural, historical, and religious context which produced the North Sámi and Greenlandic fin-de-siècle Bible translations, the two versions reflect very different translational strategies: the North Sámi translators opted for a foreignising approach employing formal equivalents whereby unfamiliar concepts were 
rendered by means of loanwords, whereas Kleinschmidt adopted a largely domesticating strategy in the Greenlandic translation, with alien flora, fauna, and other such terminology presented via dynamically equivalent Greenlandic terms and descriptive explanatory circumlocutions. This North Sámi strategy of formal equivalence has parallels in Bible translations from other parts of the world in the same period (though it is unclear whether the North Sámi translators were aware of this); for example, nineteenth-century translations into Polynesian languages such as Tahitian and Samoan make extensive use of loanwords from the original Hebrew to render unfamiliar concepts (Rubin 2013). By contrast the Greenlandic domesticating and descriptive approach has a parallel in early Cree Bible translations (Careless 2001).

This difference between the North Sámi and Greenlandic translations is noteworthy because it contradicts the possible expectation that the same foreignising approach would be used for the two minority languages since both have a shared history of Scandinavian linguistic, religious, and cultural domination. Specifically, both translations were rooted the same Scandinavian Protestant (Lutheran) religious tradition, and as such theological differences do not seem have played a role in the striking differences between the two texts. We propose four contributing factors underpinning the divergent strategies evident in the two translations despite their common sociolinguistic, cultural, and historical settings. First, the translators of the Bibles had different linguistic affinities. Although not an ethnic Greenlander, Kleinschmidt was born and raised in Greenland and was a native speaker of the language. This may have contributed to his awareness of the need to adapt the translation so that the target audience would easily understand it, which lent him to employ dynamic equivalents and descriptive words. Moreover, Kleinschmidt played an active role in the conservation and promotion of the Greenlandic language through his linguistic work (e.g. a Greenlandic grammar [Kleinschmidt 1851], a Greenlandic-Danish dictionary [Kleinschmidt 1871], and the development of an orthography) and thus had a particular interest in Greenlandic language planning. By contrast, the Norwegian Sámi Mission in charge of the North Sámi version was not a Sámi-led enterprise and, as such, the translators are less likely to have been concerned with these issues. Second, there were different levels of bilingualism among the readerships. In the late nineteenth century Greenlanders were much less likely to have been bilingual in Danish than North Sámi speakers would have been in Norwegian. As such, the North Sámi speakers would have been more familiar with earlier Norwegian Bible translations, and thus were already likely to have been introduced to these foreign concepts through those versions. Third, differences in the structural makeup of the North Sámi and Greenlandic languages themselves contributed to the different 
translation strategies. As Petterson (2012: 143) has pointed out, the polysynthetic nature of the Greenlandic language and its innate proclivity for complex descriptive lexical items is such that it readily lends itself to the creation of highly descriptive neologisms. Conversely, North Sámi has a very different structure and a long history of borrowing from Scandinavian languages. Fourth, Kleinschmidt was following an established precedent of descriptive neologisms in the partial Greenlandic Bible translations dating back to the first New Testament version, produced by Poul Egede in 1766 (see Petterson 2012: 143). The North Sámi translation lacked such a tradition.

This study is intended to serve as a pilot for a larger examination of different translation strategies for Arctic languages outside of the Scandinavian sphere of influence, such as Komi, which developed in a Russian context, and Canadian Inuktitut, in order to build up a more comprehensive picture of the tendencies towards formal as opposed to dynamic equivalence.

\section{References}

Austrheim, Gunnar et al. 2008. Sheep Grazing in the North-Atlantic Region - A Long Term Perspective on Management, Resource Economy and Ecology. Trondheim: Det skapende universitet.

Careless, Sue. 2001. "Native Elder Translating the Bible into Cree.” Anglican Journal 127 (8): 14.

Du Toit, Jaqueline S. and Jackie A. Naudé. 2005. "Lost in Translation: Designation, Identification and Classification of Flora in Translated Biblical Hebrew Texts." Journal of Northwest Semitic Languages 31 (2): 25-50.

Even-Shoshan, Abraham. 2003. The Even-Shoshan Dictionary: Revised and Updated for the $21^{\text {st }}$ Century (in Hebrew), 6 vols. Ed. Moshe Azar, Ilana Shamir, and Ya'el Yannai. N.P., Israel: HaMilon HeHadash.

Hope, Edward R. 2005. All Creatures Great and Small: Living Things in the Bible. New York: United Bible Societies.

Gröntved, Johannes. 1954. "Kvanen - dens udbredelse og anvendelse." Grønland: det grønlandske selskab 2 (3): 111-114.

Kleivan, Inge. 1979. "Studies in the Vocabulary of Greenlandic Translations of the Bible." Pages 175-189 in Eskimo Languages: their Present-Day Conditions. Edited by Bjarne Basse and Kirsten Jensen. Aarhus: Arkona. 
Kleinschmidt, Samuel. 1851. Grammatik der grönländischen Sprache: mit theilweisem Einschluss des Labradordialects. Berlin: G. Reimer.

— 1871. Den grønlandske ordbog. Copenhagen: H. F. Jørgensen.

- 1900. Atuagarssuit. Copenhagen: A. Rosenbergs Bogtrykkeri.

Koops, Robert G. 1995. “Of Gopher and Galbanum: Translating Biblical Flora into Nigerian Languages." The Bible Translator 46 (4): 423-427.

—. 1998. “'The Oil Tree' and 'Dove's Dung': Translating Flora in 1-2 Kings.” The Bible Translator 49 (2): 207-15; (4): 401-8.

Koops, Robert and Donald Slager. 2012. Each According to Its Kinds: Plants and Trees in the Bible. London: United Bible Societies.

Marias, Kobus. 2014. Translation Theory and Development Studies: A Complexity Theory Approach. New York: Routledge.

- 2019. A (Bio)semiotic Theory of Translation: The Emergence of Social Cultural Reality. New York: Routledge.

Miller-Naudé, Claudia L. and Jackie A. Naudé. 2018. "Editorial Theory and the Range of Translations for 'Cedars of Lebanon' in the Septuagint'. HTS Teologiese Studies/Theological Studies 74 (3): a5059.

Musselman, Lytton J. 2012. A Dictionary of Bible Plants. Cambridge: Cambridge University Press.

Naudé, Jackie A. and Claudia L. Miller-Naudé. 2018. "Lexicography and Translation of 'Cedars of Lebanon' in the Septuagint”. HTS Teologiese Studies/Theological Studies 74 (3): a5042.

Nida, Eugene A. 1964. "Principles of Correspondence." Repr. in The Translation Studies Reader, ed. Lawrence Venuti, 3rd ed., 141-155. London: Routledge, 2012.

Nida, Eugene A. and Charles R. Taber. 1969. The Theory and Practice of Translation. Repr., Leiden: Brill, 2003.

Nielsen, Flemming A. J. 2012. "The Earliest Greenlandic Bible: A Study of the Ur-Text from 1725.” Pages 113-138 in Ideology, Culture, and Translation. Edited by Scott S. Elliott and Roland Boer. Atlanta: Society of Biblical Literature.

Petterson, Christina. 2012. "Configuring the Language to Convert the People: Translating the Bible in Greenland." Pages 139-150 in Ideology, Culture, and Translation. Edited by Scott S. Elliott and Roland Boer. Atlanta: Society of Biblical Literature. 
Posner, Michael. 2012. "Translation Makes Bible Available to Inuktitut Speakers." The Globe and Mail, June 3, https://www.theglobeandmail.com/news/national/translation-makesbible-available-to-inuktitut-speakers/article4227710/. Accessed 05/08/18.

Rubin, Aaron D. 2013. "Polynesian Languages, Hebrew Loanwords in." Pages 176-177 in Encyclopedia of Hebrew Language and Linguistics, vol. 3. Edited by Geoffrey Khan et al. Leiden: Brill.

United Bible Societies. 1980. Fauna and Flora of the Bible. 2nd ed. London: United Bible Societies.

Venuti, Lawrence. 2008. The Translator's Invisibility: A History of Translation. 2nd ed. London: Routledge.

Zohary, Michael. 1962. Plant Life of Palestine: Israel and Jordan. New York: Ronald Press Company.

-1973. Geobotanical Foundations of the Middle East. 2 vols. Stuttgart and Amsterdam: Gustav Fischer Verlag and Swets and Zeitlinger.

1982. Plants of the Bible: A Complete Handbook to All the Plants with 200 Full-Color Plates Taken in the Natural Habitat. Cambridge: Cambridge University Press. 